\title{
EKSPANSJA PRZEPISÓW OCHRONNYCH NA NIEPRACOWNICZE STOSUNKI ZATRUDNIENIA - ROZWAŻANIA DE LEGE LATA I DE LEGE FERENDA NA PRZYKŁADZIE UMÓW ZLECENIA - ZAGADNIENIA WYBRANE
}

\begin{abstract}
Expansion of protective provisions for non-employee employment relations - considerations de lege lata and de lege ferenda on the example of commission contracts - selected issues
\end{abstract}

The article addresses the issue of extending the provisions of a protective nature to increasingly common civil-law employment relations. The starting point of the considerations is the question whether the very fact of concluding a civil law contract justifies depriving the person performing the work of the possibility of including this relationship with any norms of a protective nature characteristic of legal relations. Searching for the answer to such a question comes first to the characteristics of the current labor market. In addition, the author has shown to what extent the labor law provisions, by way of current amendments, have covered civil law employment relations.

The merit of the article is the author's argued position to what extent the protective provisions of labor law should include employment relations established on the basis of the mandate contract.

Słowa kluczowe: zatrudnienie prawnopracownicze, zatrudnienie cywilnoprawne, przepisy ochronne, rynek pracy, związki zawodowe, minimalna stawka godzinowa

Key words: labor-law employment, protective nature regulations, civil-law employment, labor market, trade unions, the minimum hourly rate

Rozpoczynając analizę zagadnienia ekspansji przepisów prawa pracy na stosunki cywilnoprawne i aksjologiczne uzasadnienia takich przeobrażeń, należy powrócić do genezy prawa pracy jako odrębnej gałęzi prawa prywatnego. Początki procesu wyodrębnienia się prawa pracy z gałęzi prawa cywilnego podyktowane była rynkową sytuacją osób świadczących pracę na rzecz innych podmiotów. Zasada wolności pracy, na której w okresie początków kapitalizmu opierały się stosunki zatrudnienia, a wyrazem jej była niczym nieograniczona swoboda umów, zakładała równorzędność stron umowy, 
co pozostawało w jaskrawej sprzeczności z sytuacją faktyczną podmiotów. Przewaga ekonomiczna podmiotu zatrudniającego oraz nadmiar siły roboczej na rynku pracy, a także brak środków do życia najniższych warstw społecznych, pozwalały pracodawcy na jednostronne kształtowanie warunków pracy i płacy pracownika. Sytuacja rynkowa i konieczność interwencji w stosunki zatrudnienia doprowadziły do stopniowych przeobrażeń, w wyniku których doszło do wyodrębnienia gałęzi prawa pracy ${ }^{1}$.

W procesie kształtowania się norm prawa pracy determinantem ich powstania i siłą sprawczą była sfera ochrony praw osób zatrudnionych. Obecnie nadal podkreśla się silną rolę funkcji ochronnej prawa pracy, stawiając ją zarówno jako cel regulacji, jak i skutek społeczny tychże norm².

Przez lata najbardziej typową i powszechnie stosowaną podstawą nawiązania stosunku zatrudnienia była umowa o pracę. Taki obraz rynku pracy, na którym zatrudnienie, co do zasady, wiązało się z pracą na umowę o pracę, uzasadniał w pełni objęcie ochroną prawa pracy jedynie prawnopracownicze stosunki zatrudnienia. Obecnie pojawiają się w doktrynie coraz bardziej stanowcze opinie mówiące o dysfunkcji prawa pracy w obliczu masowej skali niepracowniczego, cywilnoprawnego zatrudnienia ${ }^{3}$.

Historyczne uwarunkowania wyodrębnienia się gałęzi prawa pracy stanowią punkt wyjścia do dalszych rozważań nad kierunkami postulowanych przemian norm gałęzi prawa pracy. Analizując obecną sytuację na rynku pracy i strukturę zatrudnienia, należy mieć na względzie nadrzędny cel i funkcję, jaką wypełniać mają normy prawa pracy, stanowiące przyczynek do dalszych rozważań. Należy wziąć pod uwagę wyraźny dysonans pomiędzy gwarancjami ochrony stosunku pracy i sytuacji pracownika oraz warunków świadczenia pracy i stabilności zatrudnienia osób zatrudnionych w ramach stosunków cywilnoprawnych. Poważne wątpliwości, które rodzą się podczas rozważań nad zagadnieniem rzeczywistej ochrony przez prawo pracy osób, świadczących pracę na rzecz innych podmiotów, uzasadnia kwestia powszechności zawierania umów cywilnoprawnych, w szczególności umów zlecenia4.

${ }^{1}$ Zob. T. Wyka, Miejsce prawa pracy w systemie prawa polskiego, w: Zarys systemu prawa pracy. Część I. Część ogólna prawa pracy, K.W. Baran (red.), Warszawa 2010, s. 141-146; J. Jończyk, Prawo pracy, Warszawa 1995, s. 17 i n.

2 Zob. B. Antczak, Ochrona interesu pracodawcy a funkcje prawa pracy, Praca i Zabezpieczenie Społeczne 2016, 9, s. 2.

${ }^{3}$ Por. J. Jończyk, Najem pracy, Praca i Zabezpieczenie Społeczne 2016, 12, s. 2.

${ }^{4}$ W 2015 r. liczba osób pracujących w gospodarce narodowej wynosiła 14 504,3 tys. osób, z czego 11486200 w sektorze prywatnym, w tym liczba osób zatrudnionych na podstawie umowy cywilnoprawnej to ok. 1,3 mln (https://stat.gov.pl/files/gfx/portalinformacyjny/pl/defaultaktualnosci/5474/9/4/1/wybrane_zagadnienia_rynku_pracy_2015.pdf [dostęp: 18.03.2018]), zatrudnienie na podstawie umów zlecenia stanowi obecnie 66\% wszystkich cywilnoprawnych stosunków zatrudnienia (file:///C:/Users/zgkal/ Downloads/notatka_nietypowe_formy_zatrudnienia_2016_01_27.pdf; https://stat.gov.pl/obszary-tematyczne/rynek-pracy/pracujacy-zatrudnieni-wynagrodzenia-koszty-pracy/wybrane-zagadnienia-rynku-pracy-liczba-osob-z-minimalnym-wynagrodzeniem-samozatrudnieni-umowy-zlecenia-o-dzielo-dane-za-2016-rok,9,5.html [dostęp: 18.03.2018]). 
Nie ulega wątpliwości, co potwierdza jednolite stanowisko judykatury, że praca może być zarówno świadczona na podstawie cywilnoprawnych form zatrudnienia, jak $\mathrm{i}^{5} \mathrm{~W}$ warunkach i na zasadach określonych w prawie pracy. Świadczenie pracy na podstawie przepisów prawa cywilnego nie stanowi naruszenia przepisu art. 24 Konstytucji RP6 6

W moim przekonaniu pogłębionej analizie należałoby jednak poddać pogląd, iż zróżnicowanie sytuacji prawnej pracownika i strony umowy cywilnoprawnej nie stanowi naruszenia art. 32 Konstytucji $\mathrm{RP}^{7}$. Co do zasady praca w warunkach prawnopracowniczych w istocie różni się od pracy określonej w przepisach prawa cywilnego. Nie pozostawia wątpliwości, iż swoiste odrębności wynikają z samego rodzaju umowy zawartej z pracownikiem. Essentialia negotii umów cywilnoprawnych są odmienne od umów prawnopracowniczych. Warto jednakże rozważyć, czy sam fakt zawarcia umowy cywilnoprawnej uzasadnia pozbawienie osoby wykonującej pracę możliwości objęcia tego stosunku wszelkimi normami o charakterze ochronnym, charakterystycznymi dla stosunków prawnopracowniczych.

Warto podkreślić doniosłą rolę, jaką powinna odgrywać rzeczywista sytuacja rynkowa osób wykonujących pracę, w pracach nad uzasadnionymi zmianami przepisów prawa pracy. Rozszerzenie zakresu obowiązywania norm prawa pracy nie jest postulatem nowym. Nowelizacja Kodeksu pracy (kp) dokonana na mocy ustawy z 13 kwietnia 2007 r. o Państwowej Inspekcji Pracy ${ }^{8}$ wprowadziła zmiany w zakresie obowiązywania obowiązków przewidzianych w art. $207 \$ 2 \mathrm{kp}$, rozszerzając ten zakres. Ustanowiła ona obowiązek zapewnienia bezpiecznych i higienicznych warunków pracy osobom fizycznym wykonującym pracę na innej podstawie niż stosunek pracy, a także osobom prowadzącym własną działalność gospodarczą w zakładzie pracy lub w miejscu wskazanym przez pracodawcę. Tym samym, pomimo brzmienia art. 1, Kodeks pracy określa nie tylko prawa i obowiązki pracowników i pracodawców, albowiem zakres obowiązywania jego norm został rozszerzony na podmioty zatrudniające osoby na podstawie cywilnoprawnych stosunków zatrudnienia.

Kolejnym przykładem rozszerzenia zakresu obowiązywania norm prawa pracy na stosunki cywilnoprawne jest przepis art. $303 \mathrm{kp}$, który daje podstawy do objęcia prawnopracowniczą ochroną osób świadczących pracę na podstawie pracy nakładczej. Na podstawie przepisu tego artykułu Rada Ministrów wydała Rozporządzenie w sprawie uprawnień pracowniczych osób wykonujących pracę nakładczą ${ }^{9}$.

Następnym, godnym uwagi przykładem rozszerzenia zakresu obowiązywania norm prawa pracy na stosunki cywilnoprawne jest wyrok Trybunału Konstytucyjnego (TK) $\mathrm{z}$ dnia 2 czerwca 2015 r. $^{10}$, w którym uznano za niekonstytucyjny przepis art. 2 ust. 1

${ }^{5}$ Por wyrok SN z dnia 9 grudnia 1999 r., I PKN 432/99, OSNAPiUS 2001, nr 9, poz. 310.

${ }^{6}$ Por. A. Sobczyk, Prawo pracy w świetle Konstytucji RP, Warszawa 2013, s. 52 i n.

7 Wyrok SN z dnia 7 października 2004 r., II PK 29/04, OSNP 2005, nr 7, poz. 97.

${ }^{8}$ Ustawa z dnia 13 kwietnia 2007 r. o Państwowej Inspekcji Pracy (Dz. U., Nr 89, poz. 589).

9 Rozporządzenie Rady Ministrów z dnia 31 grudnia 1975 r. w sprawie uprawnień pracowniczych osób wykonujących pracę nakładczą (Dz. U. 1976, Nr 3, poz. 19 ze zm.).

${ }_{10}$ Wyrok TK z dnia 2 czerwca 2015 r., K 1/13 (Dz. U., poz. 791). 
ustawy o związkach zawodowych. TK orzekł, że podmiotem wolności zrzeszania się w związkach zawodowych powinni być pracownicy w konstytucyjnym znaczeniu tego pojęcia. Status pracownika, zdaniem TK, powinien być oceniany przez odwołanie się do kryterium wykonywania pracy zarobkowej. Ustawodawca został zobowiązany przez TK do urzeczywistnienia swobody zrzeszania się w związkach zawodowych dla wszystkich, którzy wykonują pracę zarobkową, niezależnie od tego, czy świadczą pracę w ramach stosunku pracy, umowy zlecenia czy umowy o dzieło itd. Warto w tym miejscu nadmienić, że dopuszczalność swobody zrzeszania się w związkach zawodowych osób zatrudnionych na innej podstawie niż stosunek prawnopracowniczy nie może być utożsamiana z korzystaniem z przywilejów wynikających chociażby z art. 32 ustawy o związkach zawodowych, a dotyczących szczególnej ochrony trwałości stosunku zatrudnienia ${ }^{11}$.

Innym przykładem ekspansji prawa pracy jest ustawa o minimalnym wynagrodzeniu za pracę w brzmieniu z 22 lipca 2016 r., której to nowelizacja weszła w życie od 1 stycznia 2017 r. ${ }^{12} \mathrm{Na}$ mocy przepisów powołanej ustawy wprowadzona została minimalna stawka godzinowa dla osób pracujących w ramach umowy zlecenia. Dotychczas ustawa o minimalnym wynagrodzeniu określała, na mocy art. $10 \$ 2 \mathrm{kp}$, poziom tego wynagrodzenia jedynie w odniesieniu do osób zatrudnionych w ramach prawnopracowniczych stosunków zatrudnienia.

Powyższe przykłady stopniowej ewolucji zakresu obowiązywania norm prawa pracy są próbą stopniowego dostosowywania zakresu obowiązywania norm ochronnych prawa pracy do aktualnej sytuacji rynkowej.

W moim przekonaniu zakres tejże ochrony jest nadal niewystarczający.

Ustawodawca przewidział dopuszczalność rozszerzenia zakresu stosowania przepisów prawa pracy na inne niż pracownicze stosunki zatrudnienia, formułując upoważnienie w tym zakresie względem Rady Ministrów ${ }^{13}$. Pomimo realnej, rynkowej potrzeby podyktowanej sytuacją osób świadczących pracę w ramach cywilnoprawnych stosunków zatrudnienia, Rada Ministrów nie skorzystała ze wspomnianego upoważnienia.

Dla porząadku rozważań, które są przedmiotem niniejszego artykułu, punktem wyjścia do dalszej analizy niech będzie odniesienie się do cech stosunku pracy, omówionych w kontekście cech wyróżniających cywilnoprawny stosunek zatrudnienia w ramach umowy zlecenia. Poziom uwarunkowań szczególnych i stopnia zróżnicowania cech szczególnych stosunku prawnopracowniczego i cywilnoprawnego pozwoli bowiem odnieść się do głównej tezy niniejszego artykułu, sprowadzającej się do twierdzenia, że stan prawny, w którym osoby świadczące pracę nie są objęte, co do zasady, przepisami o charakterze ochronnym, stanowi naruszenie gwarancji równego traktowania sformułowanej w art. 32 Konstytucji RP. Warto poddać bowiem pod rozwagę, czy występujące pomiędzy nimi

${ }^{11}$ Ustawa z dnia 23 maja 1991 r. o związkach zawodowych (Dz. U., Nr 55, poz. 234 ze zm.).

12 Ustawa z dnia 10 października 2002 r. o minimalnym wynagrodzeniu za pracę (Dz. U., Nr 200, poz. 1679 ze zm.).

13 Zob. art. $303 \$ 2 \mathrm{kp}$. 
różnice są na tyle istotne, iż uzasadniają pozbawienie zleceniobiorców ochrony, która jest charakterystyczna dla stosunków opartych na przepisach prawa pracy.

Cechy wyróżniające stosunek pracy, podlegający ochronie na gruncie przepisów prawa pracy, dające podstawę na jego dyferencjację względem innych stosunków zatrudnienia, zostały określone w art. $22 \mathrm{kp}$. W pierwotnym brzmieniu art. 22 ustawodawca odniósł się jedynie do zobowiązaniowego charakteru zatrudnienia, stanowiąc, że obowiązkiem pracownika jest wykonywanie pracy na rzecz zakładu pracy, a obowiązek pracodawcy (zakładu pracy) sprowadza się do wypłaty wynagrodzenia. Powyższa formuła nasuwała wątpliwości, jak szeroki zakres zatrudnienia został objęty ochroną prawa pracy.

$\mathrm{Na}$ drodze nowelizacji z 2 czerwca 1996 r. dodana została cecha kierownictwa pracodawcy jako element wyróżniający stosunek pracy ${ }^{14}$.

Aktualne brzmienie przepisu, które sprowadza się do określenia, iż stosunkiem pracy jest wykonywanie pracy określonego rodzaju na rzecz pracodawcy i pod jego kierownictwem oraz w miejscu i czasie przez niego wyznaczonym, jest wynikiem nowelizacji dokonanej 29 listopada 2002 r. Treść aktualnie obowiązującego przepisu art. $22 \mathrm{kp}$ pozwala na wyraźną delimitację stosunków pracowniczych od stosunków cywilnoprawnych, co nie było tak jednoznaczne na gruncie przepisów obowiązujących w poprzednim stanie prawnym. Obecnie, podejmując próby dokonania wyraźnego podziału pomiędzy pracą wykonywaną w ramach stosunku pracy a pracą wykonywaną w ramach umów zlecenia, wątpliwości generuje wprowadzenie przez judykaturę pojęcia „podporządkowania autonomicznego". Pojęcie to nie zostało zdefiniowane na gruncie ustawowym. Realna potrzeba wprowadzenia powyższej kategorii była podyktowana niedostosowaniem kategorii kierownictwa - podporządkowania w rozumieniu dotychczasowym - do niektórych rodzajów prac świadczonych przez pracowników w ramach stosunków pracowniczych. Coraz częściej świadczenie pracy przez pracowników, w szczególności zatrudnionych na stanowiskach kierowniczych, wykonujących prace koncepcyjne czy twórcze ${ }^{15}$, nie wiąże się z rzeczywistym kierownictwem przełożonego w rozumieniu wydawania poleceń w zakresie sposobu wykonania powierzonych mu zadań. Warto wskazać, że zdaniem Sądu Najwyższego (SN) podporządkowanie autonomiczne polega na tym, że zostają wyznaczone pracownikowi przez pracodawcę zadania do wykonania, przy jednoczesnym pozostawieniu pewnego marginesu swobody, co do sposobu ich realizacji ${ }^{16}$.

Nie pozostawia wątpliwości, że społeczno-gospodarcze warunki pracy oraz stopniowa specjalizacja i profesjonalizacja pracy wymusiły niejako na judykaturze przyjęcie koncepcji definiowania kryterium podporządkowania w sposób odmienny od dotychczasowego. Pominięcie problemu spowodowałoby brak możliwości uznania za pracę w ramach

${ }^{14}$ Na temat historycznego kształtowania się prawa pracy w Polsce zob. A.M. Świątkowski, Kontynuacja izmiana instytucji indywidualnego prawa pracy w Polsce, Studia z Zakresu Prawa Pracy i Polityki Społecznej 1999/2000, A.M. Świątkowski (red.), Kraków 2001, s. 59-147.

${ }^{15}$ Wyrok SN z dnia 7 września 1999 r., I PKN 277/99.

16 Tamże. 
stosunków pracowniczych podmiotów wykonujących prace chociażby w takich zawodach, jak radca prawny, lekarz, sędzia, nauczyciel akademicki. Wyraźne zbliżenie stosunku zatrudnienia, w którym mamy do czynienia z podporządkowaniem autonomicznym, względem zatrudnienia w ramach umów zlecenia można zaobserwować w kontekście wyroku SN, w którym stwierdzone zostało, że osoba zajmująca stanowisko kierownicze może świadczyć pracę w ramach tzw. podporządkowania autonomicznego ${ }^{17}$. Koncepcja taka utożsamia niekiedy funkcję podporządkowania jako podleganie pracownika określonym zadaniom, nie zaś osobom - przełożonym. Swoboda ta nie może być jednakże utożsamiana $z$ wykluczeniem uprawnień wydawania przez przełożonego poleceń, zmierzających do konkretyzacji obowiązków pracownika. Mając na uwadze dopuszczalność uznania, że na stanowiskach kierowniczych mogą być zatrudniane osoby w ramach stosunków prawnopracowniczych, oraz mając na względzie charakter zadań, funkcji i sposobu wypełniania obowiązków, należy stwierdzić, że w szczególnych sytuacjach osoby zatrudnione w ramach stosunków prawa pracy mogą samodzielnie kształtować swój czas pracy, miejsce pracy oraz realizować proces pracy w określony przez siebie sposób. Pomimo znacznej samodzielności osób wykonujących prace w warunkach podporządkowania autonomicznego korzystają oni z ochrony zagwarantowanej w przepisach prawa pracy.

Czy zatem uzasadnione jest tak znaczące zróżnicowanie sytuacji osób świadczących pracę w ramach stosunków pracowniczych względem osób zatrudnionych na podstawie umów zlecenia?

Aby sformułować konkluzję, dającą odpowiedź na tak postawione pytanie, należałoby się jeszcze odnieść do zagadnienia podporządkowania w stosunkach cywilnoprawnych. Formalnie, w stosunkach cywilnoprawnych ex lege nie występuje element podporządkowania podmiotowi zatrudniającemu. W wyroku SN podkreślił, że w umowie zlecenia określony jest rodzaj wykonywanych czynności. $Z$ istoty umowy wynika, że nie może ona polegać na pozostawaniu w dyspozycji zlecającego, stosownie do jego potrzeb i czynności zlecanych na bieżąco ${ }^{18}$. Można uznać, że jest to główna cecha różnicująca stosunek pracy od stosunku opartego na umowie zlecenia, albowiem już samodzielność zleceniobiorcy w zakresie zarówno sposobu wykonywania powierzonych zadań, jak i czasu oraz miejsca ich wykonywania może być w umowie ograniczona. Brak elementu podporządkowania w stosunkach cywilnoprawnych opartych na umowach zlecenia nie jest bezsporny. Niemniej jednak pozbawienie podmiotu zatrudniającego na podstawie umowy zlecenia uprawnień w zakresie określania sposobu wykonania zlecenia byłoby daleko idącym nadużyciem.

Konkludując, rozróżnienie stosunku pracy od stosunku opartego na cywilnoprawnej umowie zlecenia sprowadza się na, co do zasady, braku możliwości zlecania zleceniobiorcy czynności bieżących, wynikających z aktualnych potrzeb podmiotu zatrudniającego.

17 Wyrok SN z dnia 7 marca 2006 r., I PK 146/05.

18 Wyrok SN z dnia 15 października 1999 r., I PKN 307/99. 
Wydaje się, że poziom ochrony zagwarantowanej przepisami prawa pracy oraz uproszczona forma dochodzenia roszczeń przed sądem pracy, względem warunków zatrudnienia osób pracujących w ramach stosunków cywilnoprawnych, nie mogą być podyktowane jedynie powyższą kwestią.

Bez wątpienia cechą stosunku pracy jest jego dobrowolność. Niezależnie od podstawy zatrudnienia wszystkie prawnopracownicze stosunki zatrudnienia charakteryzuje dwustronność oświadczeń woli w wymiarze materialnym. Cecha ta wynika wprost z przepisu art. $11 \mathrm{kp}$. Powyższa cecha pozwala na wyraźne odróżnienie zatrudnienia prawnopracowniczego od zatrudnienia penalnoprawnego, którego podstawą jest realizacja określonego przymusu prawnego.

Kolejną cechą, która nie nasuwa poważniejszych wątpliwości jest obowiązek osobistego świadczenia pracy. Istotą stosunku podlegającego ochronie prawnopracowniczej jest świadczenie pracy przez podmiot zatrudniony, nie zaś osiągnięcie zakładanego w umowie skutku. Należy podkreślić, że wszystkie umowy prawnopracownicze są umowami starannego działania, nie zaś umowami rezultatu. Również umowa zawierana na czas wykonania określonego zadania, która była jedną z umów o pracę przed wejściem w życie nowelizacji z 2015 r., była umową starannego działania.

Powyższa cecha pozwala na delimitację umów o dzieło od zatrudnienia prawnopracowniczego. Niemniej jednak umowy zlecenia czy umowy o świadczenie usług są podobnie jak umowy o pracę umowami starannego działania.

Warto poddać pod rozwagę, na ile obecny kształt przepisów, w szczególności przepisu art. $22 \mathrm{kp}$, stanowi realną ochronę dla osób zatrudnionych. Powszechność stosunków cywilnoprawnych jako podstawy zatrudnienia może nasuwać pewne wątpliwości.

Mając na względzie ograniczoną objętość niniejszego artykułu oraz niezwykłą złożoność podjętej problematyki, w rozważaniach nad uzasadnieniem dla pozbawienia ochrony zatrudnionych w ramach stosunków cywilnoprawnych odniosę się do dwóch zasadniczych kwestii.

Z aprobatą należy przyjąć uzasadnienie do projektu Kodeksu pracy, który w księdze ósmej wprowadza ochronę względem osób zatrudnionych w stosunkach niepracowniczych ${ }^{19}$. Konstatacja, iż w pewnych przypadkach zatrudnienie niepracownicze jest wykonywane w warunkach upodabniających je do zatrudnienia pracowniczego, jest w pełni uzasadnione, na co wskazują poczynione przeze mnie powyżej rozważania. W szczególności potrzeba ochrony wydaje się aktualna w sytuacji, gdy osoba pozostająca w zatrudnieniu niepracowniczym świadczy pracę osobiście i za wynagrodzeniem. Istotą jest, aby praca miała charakter ciągły lub powtarzający się oraz była świadczona na rzecz tego samego podmiotu zatrudniającego. Nie ulega wątpliwości, iż ciągłość oraz powtarzający się charakter pracy to pojęcia nieostre. Wprowadzenie konkretnych kwalifikatorów w postaci krotności świadczonej pracy bądź długości zatrudnienia jest w tym miejscu, w moim przekonaniu, niecelowe. Zastosowanie pojęć nieostrych

19 Uzasadnienie do projektu Kodeksu pracy znajduje się na stronie: https://www.mpips.gov.pl/prawo-pracy/projekty-kodeksow-pracy/ (dostęp: 18.03.2018). 
umożliwi stosownym organom indywidualne rozstrzygnięcia, przyjęte po analizie poszczególnych przypadków.

Określając poziom ochrony, podkreślono, że został on ograniczony ze względu na fakt, że ochrona nie może niweczyć gospodarczych walorów tychże stosunków. Takiego poglądu nie można przyjąć $\mathrm{z}$ aprobatą. Nie należy oczekiwać, iż poziom ochrony zagwarantowany osobom świadczącym pracę $\mathrm{w}$ ramach cywilnoprawnych stosunków zatrudnienia będzie tożsamy z ochroną pracowników. Uzasadniony jest postulat, by poziom ochrony uwzględniał specyfikę zatrudnienia. Niewątpliwie należy mieć na względzie, co zostało stwierdzone w uzasadnieniu do kodeksu, iż osoby wykonujące zatrudnienie niepracownicze są z reguły wykonawcami usług zachowującymi samodzielność w ich świadczeniu. Perspektywa spojrzenia na stosunek zatrudnienia z punktu widzenia przedsiębiorcy nie jest jednakże perspektywą, którą należy zaaprobować i która powinna być uznana za kluczową.

Przepisami, które bez wątpienia powinny objąć cywilnoprawne stosunki zatrudnienia, są przepisy indywidualnego prawa pracy, w szczególności dotyczące minimalnego wynagrodzenia oraz kwestii wypowiadania umów stanowiących podstawę zatrudnienia.

Najpierw odniesiemy się do kwestii minimalnego wynagrodzenia za pracę. Jak już wspomniano, od stycznia 2017 r. obowiązuje minimalna stawka godzinowa, która ma zastosowanie zarówno względem pracowników zatrudnionych na podstawie umów o pracę, jak i umów zlecenia. Na aprobatę zasługuje ekspansja przepisów o charakterze ochronnym, jednakże nie można przeceniać aktualnie rzeczywistej siły ich oddziaływania. Podmiot zatrudniony w momencie podpisywania umowy nie ma realnych narzędzi do określenia poziomu spodziewanego wynagrodzenia, które zostanie mu wypłacone na koniec miesiąca. Przywołana regulacja będzie odgrywała właściwą rolę i spowoduje oczekiwane skutki dopiero wówczas, gdy ustawodawca zobowiąże podmiot zatrudniający do określania w umowie minimalnej liczby godzin pracy w okresie rozliczeniowym, które będą zagwarantowane do przepracowania przez biorącego zlecenia. Aby odeprzeć ewentualny sprzeciw krytyków tego postulatu, nadmienię, że w polskim prawie powszechnie obowiązującym istnieje konstrukcja w dużo większym stopniu ingerująca w zasadę swobody umów zagwarantowaną przepisami prawa cywilnego. Mamy tutaj na myśli przepisy rozporządzenia w sprawie uprawnień pracowniczych osób wykonujących pracę nakładczą, które to rozporządzenie w $\$ 3$ pkt 2 stanowi, że jeżeli praca nakładcza stanowi dla wykonawcy wyłączne lub główne źródło utrzymania, ilość pracy powinna być tak ustalona, aby jej wykonanie pozwoliło na uzyskanie wynagrodzenia nie niższego niż wynagrodzenie minimalne. Nie tylko zatem podmiot zatrudniający jest zobowiązany do określania liczby godzin, za które podmiot zatrudniony otrzyma wynagrodzenie. Ustawodawca zobligował go również, w szczególnych sytuacjach, do wypłaty wynagrodzenia w kwocie nie niższej niż minimalne wynagrodzenie za pracę, określone w przepisach powszechnie obowiązujących.

Mając na uwadze współczesną strukturę zatrudnienia, w której znaczną część stanowią właśnie umowy zlecenia, warto rozważyć, czy ewolucja przepisów o minimalnej stawce 
godzinowej nie powinna pójść o krok dalej, przywołując powyższy model poziomu wynagrodzeń wykonawców pracujących na rzecz nakładców.

Drugim, obok wynagrodzenia, kluczowym aspektem świadczenia pracy jest niewątpliwie poczucie swoistej stabilizacji. W tej sferze na pierwszy plan wysuwa się kwestia dopuszczalności wypowiedzenia i rozwiązania umów, będących podstawą świadczonej pracy.

Rozwiązanie umowy zlecenia może nastąpić poprzez wypowiedzenie złożone przez każdą ze stron. Na mocy art. $746 \S 1$ i $\$ 2$ Kodeksu cywilnego $(k c)^{20}$ zarówno dający zlecenia, jak i przyjmujący zlecenia może je, co do zasady, wypowiedzieć w każdym czasie. Kodeks cywilny nie przewiduje okresów wypowiedzenia, zatem jeśli strony w umowie nie postanowiły inaczej, umowa zostaje rozwiązana z dniem złożenia wypowiedzenia. Taki kształt regulacji bez wątpienia wpływa na brak poczucia stabilizacji zatrudnienia. Co prawda, strony mogą zastrzec w umowie określenie terminu wypowiedzenia umowy, jednakże mając na uwadze jedynie formalną równość stron i zazwyczaj rzeczywistą przewagę podmiotu zatrudniającego, trudno spodziewać się realnych możliwości wyegzekwowania przez pracobiorcę stosownych ustępstw. Co więcej, dyspozytywny charakter norm prawa cywilnego daje możliwości kształtowania przez podmiot zatrudniający sytuacji zatrudnionego w jeszcze mniej sprzyjający sposób, niż wynika to z przepisów ustawy.

Biorąc pod uwagę rzeczywistą rolę, jaką odgrywają współcześnie umowy zlecenia, które stanowią często podstawę świadczenia pracy, będącej jedynym źródłem utrzymania dla osoby zatrudnionej i jego najbliższych, swego rodzaju stabilizacja zatrudnienia powinna zostać zapewniona przez ustawodawcę. Wydaje się, że uzasadniona byłaby konstrukcja, która ma zastosowanie do osób świadczących pracę nakładczą, którym zagwarantowano jednomiesięczny okres wypowiedzenia ${ }^{21}$.

Analizując zagadnienie konieczności objęcia stosunków niepracowniczych przepisami prawa pracy, warto zasygnalizować jeszcze jedno spojrzenie na problem, tj. z punktu widzenia podmiotu zatrudniającego. W debacie na temat dopuszczalności i zakresu przepisów prawa pracy, którymi powinny zostać objęte stosunki cywilnoprawne, zazwyczaj pomijana jest kwestia przepisów o charakterze organizatorskim, które w pewnym zakresie również powinny obejmować powyższe stosunki zatrudnienia. Nawiązując do kwestii delimitacji stosunków pracy od stosunków zatrudnienia na podstawie umowy zlecenia, należy zauważyć, że postrzeganie powyższego wyboru pomiędzy rodzajem umowy, jako leżącej jedynie w gestii pracodawcy, nie jest w pełni uzasadnione. Niekiedy mamy do czynienia z sytuacją, kiedy w istocie to charakter i rodzaj świadczonej pracy determinują podstawę zatrudnienia. Zaznaczyć należy, że nie jest to zjawisko powszechne, niemniej jednak nie można zupełnie pominąć tego zagadnienia. Podnosząc kwestię funkcji organizatorskiej, uzasadnione wydaje się postulowanie o objęcie obowiązkowym okresem wypowiedzenia trybu jednostronnego wypowiedzenia umowy zlecenia.

20 Ustawa z dnia 23 kwietnia 1964 r. Kodeks cywilny (Dz. U. 1964, Nr 16, poz. 93 ze zm.).

${ }^{21} \$ 3$ Rozporządzenia Rady Ministrów z dnia 31 grudnia 1975 r. w sprawie uprawnień pracowniczych osób wykonujących pracę nakładczą (Dz. U. 1976, Nr 3, poz. 19 ze zm.). 
Na koniec rozważań, odwołując się raz jeszcze do gwarancji równego traktowania wyrażonej w art. 32, w związku z art. 65 ust. 1 Konstytucji RP, chcielibyśmy zwrócić uwage na jeden jeszcze aspekt. Mianowicie, niekiedy wybór pomiędzy podstawą zatrudnienia, tj. umową zlecenia, a umową o pracę jest wyborem pozornym. To rodzaj i charakter świadczonej pracy determinuje konieczność zastosowania jednej z powyższych form zatrudnienia. Ad exemplum podstawą świadczenia pracy przez dziennikarzy jest zazwyczaj umowa zlecenia ${ }^{22}$. Wynika to ściśle z charakteru pracy, która zazwyczaj pozbawiona jest elementu podporządkowania. Warto zatem postawić pytanie, czy mamy w istocie do czynienia z gwarancją swobody wyboru zawodu, zagwarantowaną w art. 65 Konstytucji, i realizacją gwarancji równego traktowania, skoro określone zawody, per se, determinują niejako podjęcie zatrudnienia na podstawie umów cywilnoprawnych, pozbawionych de facto elementu ochrony podmiotu zatrudnionego.

Konkludując rozważania, w sposób jednoznaczny należy wskazać, że stosunki o charakterze cywilnoprawnym, w szczególności oparte na postanowieniu umów zlecenia, powinny zostać objęte, w pewnym zakresie, przepisami prawa pracy i instytucjami wykształconymi na gruncie tejże gałęzi prawa. Uzasadnienie takiego stanowiska wynika ze znacznego podobieństwa zarówno samej pracy świadczonej w ramach tychże umów, jak i celów, jakie umowy te realizują. Zarówno umowa o pracę, jak i umowa zlecenia stanowią często jedyne źródło utrzymania dla podmiotu zatrudnionego i jego rodziny. Mając na uwadze powyższe konstatacje, tym bardziej uzasadnione wydaje się twierdzenie, że przepisy ustawowe powszechnie obowiązujące mogą być rozpatrywane w kontekście potencjalnego naruszenia zasady równego traktowania, wyrażonej w art. 32 Konstytucji RP.

\section{Bibliografia}

Antczak B., Ochrona interesu pracodawcy a funkcje prawa pracy, Praca i Zabezpieczenie Społeczne 2016, 9.

Jończyk J., Najem pracy, Praca i Zabezpieczenie Społeczne 2016, 12.

Jończyk J., Prawo pracy, Warszawa 1995.

Sobczyk A., Prawo pracy w świetle Konstytucji RP, Warszawa 2013.

Świątkowski A.M., Kontynuacja i zmiana instytucji indywidualnego prawa pracy w Polsce, Studia z Zakresu Prawa Pracy i Polityki Społecznej 1999/2000, A.M. Świątkowski (red.), Kraków 2001.

Wyka T., Miejsce prawa pracy w systemie prawa polskiego, w: Zarys systemu prawa pracy. Część

I. Czesść ogólna prawa pracy, K.W. Baran (red.), Warszawa 2010.

Ziółkowska K., Podstawy prawne zatrudnienia dziennikarzy - główne pojęcia, Media - Kultura

- Komunikacja Społeczna 2013, 9.

${ }^{22}$ K. Ziółkowska, Podstawy prawne zatrudnienia dziennikarzy - główne pojęcia, Media - Kultura Komunikacja Społeczna 2013, 9, s. 223. 
Rozporządzenie Rady Ministrów z dnia 31 grudnia 1975 r. w sprawie uprawnień pracowniczych osób wykonujących pracę nakładczą (Dz. U. 1976, Nr 3, poz. 19 ze zm.).

Ustawa z dnia 13 kwietnia 2007 r. o Państwowej Inspekcji Pracy (Dz. U., Nr 89, poz. 589).

Ustawa z dnia 10 października 2002 r. o minimalnym wynagrodzeniu za pracę (Dz. U., Nr 200, poz. 1679 ze zm.).

Ustawa z dnia 23 maja 1991 r. o związkach zawodowych (Dz. U., Nr 55, poz. 234 ze zm.).

Ustawa z dnia 23 kwietnia 1964 r. Kodeks cywilny (Dz. U. 1964, Nr 16, poz. 93 ze zm.).

Wyrok TK z dnia 2 czerwca 2015 r., K 1/13 (Dz. U., poz. 791).

Wyrok SN z dnia 7 marca 2006 r., I PK 146/05.

Wyrok SN z dnia 7 października 2004 r., II PK 29/04, OSNP 2005, nr 7, poz. 97.

Wyrok SN z dnia 7 września 1999 r., I PKN 277/99.

Wyrok SN z dnia 9 grudnia 1999 r., I PKN 432/99, OSNAPiUS 2001, nr 9, poz. 310.

https://stat.gov.pl/files/gfx/portalinformacyjny/pl/defaultaktualnosci/5474/9/4/1/wybrane_zagadnienia_rynku_pracy_2015.pdf (dostęp: 18.03.2018).

https://stat.gov.pl/obszary-tematyczne/rynek-pracy/pracujacy-zatrudnieni-wynagrodzenia-koszty-pracy/wybrane-zagadnienia-rynku-pracy-liczba-osob-z-minimalnym-wynagrodzeniem-samozatrudnieni-umowy-zlecenia-o-dzielo-dane-za-2016-rok,9,5.html (dostęp: 18.03.2018). https://www.mpips.gov.pl/prawo-pracy/projekty-kodeksow-pracy/ (dostęp: 18.03.2018). 